\title{
Implementasi Jaringan Saraf Tiruan Untuk Menentukan Kelayakan Proposal Tugas Akhir
}

Fitri Ayu

Program Studi Manajemen Informatika, AMIK Mahaputra Riau

fitriayu@amikmahaputra.ac.id

\section{Article Info}

History :

Dikirim 29 Oktober 2018

Direvisi 31 Januari 2019

Diterima 07 Februari 2019

\section{Kata Kunci :}

Artificial

Neural Network

Backpropagation

Matlab

\begin{abstract}
Abstrak
Sebuah Proposal Tugas Akhir (TA) yang diajukan mahasiswa harus diseleksi oleh Ketua Program Studi (KPS) untuk menentukan apakah proposal tersebut layak atau tidak untuk dilanjutkan sebagai salah satu syarat kelulusan, khususnya pada D3 Manajemen Informatika (MI) AMIK-ROYAL KISARAN. Proses penentuan kelayakan sebuah judul Tugas Akhir (TA) pada penelitian ini menerapkan konsep Jaringan Saraf Tiruan (JST) yang dibangun menggunakan enam kriteria sebagai input, antara lain : kesesuaian judul dengan visi Program Studi, implementasi program dalam penelitian, implementasi konsep jaringan dalam penelitian, sumber data yang digunakan, logis atau tidaknya suatu penelitian, memenuhi syarat untuk disebut sebagai sebuah sistem informasi. Ke-enam kriteria ini akan menjadi input bagi jaringan dalam melakukan pelatihan dan pengujian jaringan, dengan memvariasikan hidden layer yang digunakan. Dari penelitian yang dilakukan, dengan 40 data input di dapatkan bahwa jaringan akan membarikan hasil terbaik pada pembagian data $20 \times 20$ untuk pelatihan dan pengujian dengan pola 66-1, dimana persentase tingkat kebenaran pada pelatihan adalah $90 \%$ dan pengujian $60 \%$ dengan $\alpha=0,1$. Dari hasil perbandingan perhitungan data antara Matlab dengan perhitungan manual diperolah tingkat kepercayaan $100 \%$.
\end{abstract}

(C) This work is licensed under a Creative Commons AttributionShareAlike 4.0 International License.

\section{Koresponden:}

Fitri Ayu,

Program Studi Manajemen Informatika, AMIK Mahaputra Riau

Email : fitriayu@amikmahaputra.ac.id

\section{PENDAHULUAN}

Jaringan Saraf Tiruan (Neural Network) merupakan suatu sistem pengolahan informasi yang memiliki karakteristik mirip dengan jaringan saraf biologi, pertama kali diperkenalkan oleh McCulloch dan Pitts di tahun 1943. Proses pengolahannya mencoba mensimulasikan pembelajaran pada otak manusia menggunakan program komputer yang mampu menyelesaikan sejumlah perhitungan selama proses pembelajaran.

Metode Jaringan Saraf Tiruan (JST) semakin berkembang dengan diperkenalkannya metode Perceptron (Rosenblatt, 1958), Backpropagation (Rumelhart, 1986), sistem Kohonen dan fungsi radial basis. JST sudah banyak dimanfaatkan untuk berbagai aplikasi, seperti pengenalan pola, peramalan, klasifikasi, dan signal processing. Bidang keilmuan yang sering menggunakan proses neural network tersebut diantaranya bidang kedokteran, bisnis, dan teknologi informasi.

Penyeleksian proposal tugas akhir, skripsi, ataupun tesis merupakan permasalahan yang cukup dirasakan setiap perguruan tinggi. Khususnya bagi seorang Ketua Program Studi (KPS) yang 
berhak memutuskan apakah proposal judul tersebut dibolehkan atau tidak untuk diteliti oleh mahasiswa sebagai syarat kelulusan yang harus dipenuhi. Permasalahan timbul karena pengajuan proposal judul ibarat siklus tahunan yang selalu terjadi. Dapat dibayangkan berapa banyaknya variasi judul yang diajukan mahasiswa setiap tahunnya, dengan keterbatasan bidang ilmu yang dipelajari dan dikuasai mahasiswa.

Belum lagi penilaian kelayakan harus mempertimbangkan berbagai hal sesuai dengan visi dan misi Program Studi ataupun Institusi, seperti halnya pada Yayasan Perguruan Tinggi AMIKROYAL KISARAN. Sehingga mahasiswa yang akan dihasilkan mampu bersaing di dunia kerja. Berdasarkan hal tersebut, untuk mempercepat proses penentuan kelayakan judul Tugas Akhir (TA) perlu sebuah sistem cerdas yang dapat berfikir dan bernalar seperti sistem kerja otak manusia hingga akhirnya dapat mempercepat kinerja Program Studi.

\section{METODE PENELITIAN}

\subsection{Pengumpulan Data}

Data yang dibutuhkan pada penelitian ini adalah data Judul Tugas Akhir yang di dapatkan dari Yayasan Perguruan Tinggi AMIK ROYAL KISARAN, khususnya pada Program Studi Manajemen Informatika. Jaringan Saraf Tiruan (JST) dengan metode Backpropagation, dalam menentukan kelayakan judul Tugas Akhir menggunakan beberapa input yang telah ditetapkan, yang kemudian dapat menentukan kelayakan judul yang diajukan mahasiswa. Input-input yang digunakan adalah :

1. Kesesuaian judul dengan visi Program Studi

2. Implemantasi program dalam penelitian

3. Implementasi konsep jaringan dalam penelitian

4. Sumber data yang digunakan dalam penelitian

5. Logis atau tidaknya suatu penelitian

6. Serta memenuhi syarat untuk disebut sebagai sebuah sistem informasi.

\subsection{Konsep Teori}

\subsubsection{Konsep Jaringan Saraf Tiruan}

Jaringan Saraf Tiruan (JST) atau neural network adalah suatu metode komputasi yang meniru sistem jaringan saraf biologis. Metode ini menggunakan elemen perhitungan non-linear dasar yang disebut neuron yang diorganisasikan sebagai jaringan yang saling berhubungan, sehingga mirip dengan jaringan saraf manusia. Jaringan Saraf Tiruan (JST) dibentuk untuk memecahkan suatu masalah tertentu, seperti pengenalan pola atau klasifikasi karena proses pembelajaran.[6]

\subsubsection{Metode Backpropagation}

Backpropagation merupakan algoritma pembelajaran yang terawasi dan biasanya digunakan oleh perseptron dengan banyak lapisan untuk mengubah bobot-bobot yang terhubung dengan neuro-neuron yang ada pada lapisan tersembunyinya. Algoritma Backpropagation menggunakan error output untuk mengubah nilai bobot-bobotnya dalam arah mundur (backward). Untuk mendapatkan error ini, tahap perambatan maju (forward propagation) harus dikerjakan terlebih dahulu. Pada saat perambatan maju, neuron-neuron diaktifkan dengan menggunakan fungsi aktivasi. Untuk metode Backpropagation fungsi aktivasi yang sering digunakan diantaranya : Sigmoid Biner, Sigmoid Bipolar, Identitas. Arsitektur jaringan Backpropagation seperti terlihat pada gambar 1 dibawah ini : 


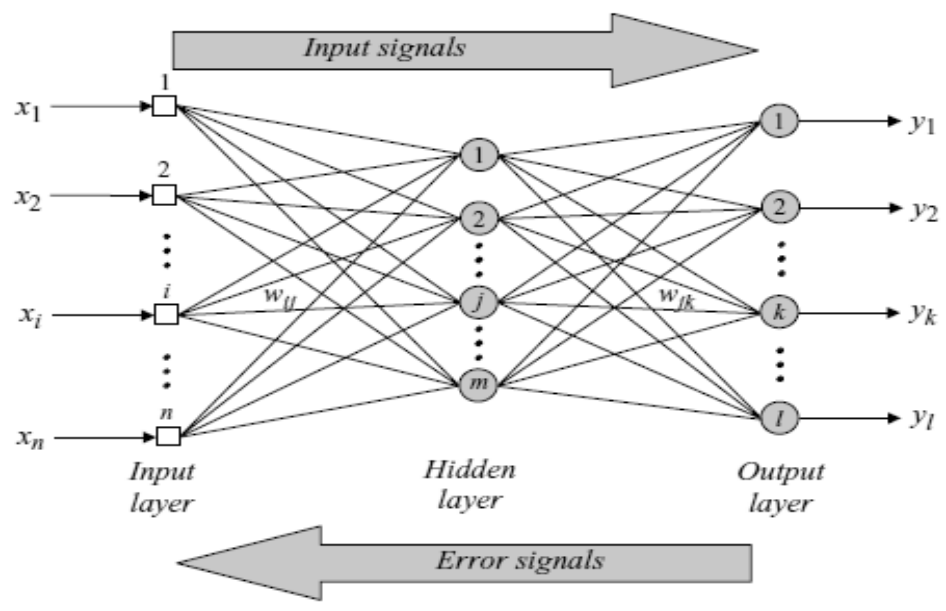

Gambar 1. Arsitektur Jaringan Backpropagation

\section{Algoritma Backpropagation}

Pelatihan dengan metode Backpropagation pada dasarnya terdiri atas tiga langkah, yaitu :

1. Data masukan ke input jaringan (feedforward)

2. Perhitungan dan propagasi balik dari error yang bersangkutan

3. Pembaharuan (adjustment) bobot dan bias

\subsubsection{Normalisasi Data}

Untuk mengkonfersikan nilai data pada suatu rentang nilai yang dapat diolah oleh jaringan, diperlukan normalisasi data, dalam algoritma Backpropagation dengan fungsi aktivasi Sigmoid, data yang ditampilkan merupakan data antara 0 dan 1, dengan demikian data yang akan di inputkan harus dinormalisasikan terlebih dahulu. Metode yang digunakan untuk normalisasi data kelayakan judul Tugas Akhir adalah metode Zero-Mean Normalization, yang mentransformasikan nilai data secara linear. Normalisasi data dengan menggunakan rumus Zero-Mean Normalization adalah sebagai berikut :

Dimana :

$$
\mathrm{X}^{\prime}=\frac{0.8(x-a)}{b-a}+0.1
$$

$$
\begin{aligned}
& 0,8=\text { Ketetapan } \\
& \mathrm{x}=\text { Nilai data ke-n } \\
& \mathrm{b}=\text { Nilai data tertinggi } \\
& \mathrm{a}=\text { Nilai data terendah }
\end{aligned}
$$

\subsection{Matlab}

Matlab singkatan dari Matrix Laboratory, di gunakan dalam pengembangan Algoritma matematika dan komputasi, pemodelan, simulasi, dan pembuatan prototype. Matlab dapat menunjukkan hasil perhitungan dalam bentuk grafik dan dapat dirancang sesuai keinginan menggunakan GUI yang dibuat sendiri.

Langkah-langkah pengolahan data menggunakan Matlab ditetapkan sebagai berikut :

1. Menetapkan data input dan target untuk pelatihan serta data input dan target pengujian

2. Menetapkan bobot awal

3. Menetapkan parameter - parameter yang digunakan

4. Melihat keluaran yang dihasilkan 
5. Melakukan pembelajaran atau pelatihan

6. Melakukan pengujian terhadap data pelatihan

7. Evaluasi ouput jaringan (data pelatihan dan target)

\section{HASIL DAN PEMBAHASAN}

Tahap pertama yang dilakukan pada penelitian ini yaitu menentukan input yang menjadi dasar untuk menentukan kelayakan judul Tugas Akhir yang diajukan mahasiswa, yaitu :

1. Kesesuaian judul dengan visi Program Studi

2. Implementasi program dalam penelitian

3. Implementasi konsep jaringan dalam penelitian

4. Sumber data yang digunakan dalam penelitian

5. Logis atau tidaknya suatu penelitian

6. Memenuhi syarat untuk disebut sebagai sebuah Sistem Informasi.

Selanjutnya menganalisa rating kelayakan terhadap kriteria input, dimana pengambilan data dilakukan dengan variabel penilaian sebagai berikut :

1. Sangat Kurang Layak (SKL) dengan point 1

2. Kurang Layak (KL) dengan point 2

3. Cukup Layak (CL) dengan point 3

4. Layak (L) dengan point 4

5. Sangat Layak (SL) dengan point 5

Semua input dirubah ke bentuk numerik dengan simbol $\mathrm{X}_{1}, \mathrm{X}_{2}, \mathrm{X}_{3}, \mathrm{X}_{4}, \mathrm{X}_{5}, \mathrm{X}_{6}$, dimana :

$\mathrm{X}_{1}$ : Kesesuaian judul dengan visi Program Studi

$\mathrm{X}_{2}$ : Implemantasi program dalam penelitian

$\mathrm{X}_{3}$ : Implementasi konsep jaringan dalam penelitian

$\mathrm{X}_{4}$ : Sumber data yang digunakan dalam penelitian

$\mathrm{X}_{5}$ : Logis atau tidaknya suatu penelitian

$\mathrm{X}_{6}$ : Memenuhi syarat untuk disebut sebagai sebuah sistem informasi

Arsitektur Jaringan Saraf Tiruan yang digunakan adalah dengan banyak lapisan (multilayer net) (Gambar 2) dengan algoritma Backpropagation dan fungsi aktivasi Sigmoid yang terdiri dari :

a. Lapisan masukan (input) dengan $6 \operatorname{simpul}\left(\mathrm{X}_{1}, \mathrm{X}_{2}, \mathrm{X}_{3}, \mathrm{X}_{4}, \mathrm{X}_{5}, \mathrm{X}_{6}\right)$

b. Lapisan tersembunyi (hidden) bervariasi (2, $3,4,5,6$ simpul) $\left(Z_{1}, Z_{2}, Z_{3}, Z_{4}, Z_{5}, Z_{6}\right)$

c. Lapisan keluaran (output) dengan 1 simpul $(Y)$

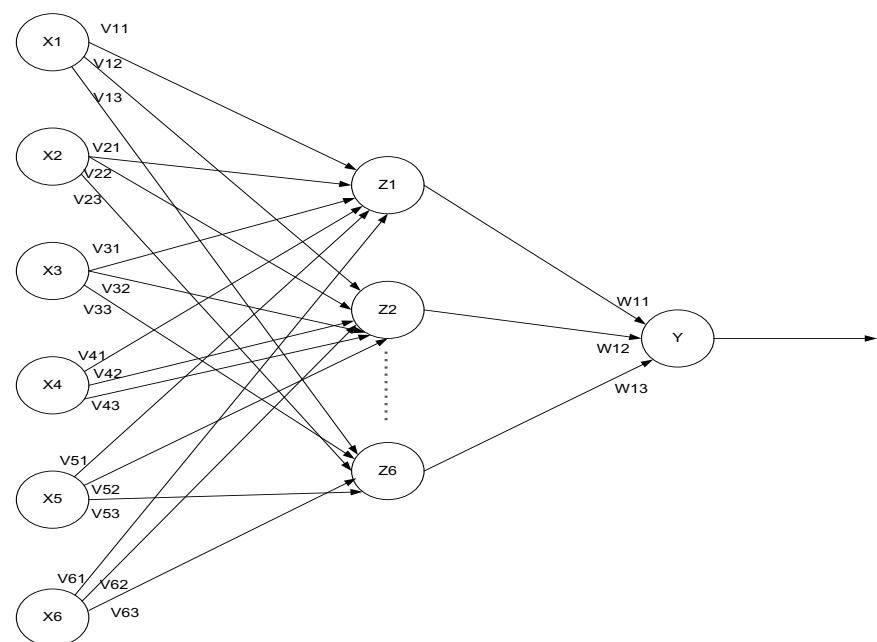

Gambar 2. Arsitektur Jaringan Saraf Tiruan Penentuan Kelayakan Judul Tugas Akhir 
Dalam penerapan konsep Jaringan Saraf Tiruan (JST) dengan metode Backpropagation, diperlukan pelatihan dan pengujian untuk memperkenalkan pola-pola dari data masukan dan keluaran yang dirancang dengan matrik P dan Q. Pembagian tersebut dapat dilihat dari tabel 1.

Tabel 1. Pola Pembagian Data Berdasarkan Jumlah Data dan Arsitektur

\begin{tabular}{|c|c|c|c|c|}
\hline \multirow{2}{*}{ No. } & \multicolumn{3}{|c|}{ Jumlah Data } & \multirow{2}{*}{$\begin{array}{c}\text { Pola } \\
\text { Arsitektur }\end{array}$} \\
\hline & Total & Pelatihan (P) & Pengujian (Q) & \\
\hline \multirow{5}{*}{1} & \multirow{15}{*}{40} & \multirow{5}{*}{20} & \multirow{5}{*}{20} & $6-2-1$ \\
\hline & & & & $6-3-1$ \\
\hline & & & & $6-4-1$ \\
\hline & & & & $6-5-1$ \\
\hline & & & & $6-6-1$ \\
\hline \multirow{5}{*}{2} & & \multirow{5}{*}{25} & \multirow{5}{*}{15} & $6-2-1$ \\
\hline & & & & $6-3-1$ \\
\hline & & & & $6-4-1$ \\
\hline & & & & $6-5-1$ \\
\hline & & & & $6-6-1$ \\
\hline \multirow{5}{*}{3} & & \multirow{5}{*}{30} & \multirow{5}{*}{10} & $6-2-1$ \\
\hline & & & & $6-3-1$ \\
\hline & & & & $6-4-1$ \\
\hline & & & & $6-5-1$ \\
\hline & & & & $6-6-1$ \\
\hline
\end{tabular}

Selanjutnya data perlu di normalisai Seperti terlihat pada tabel 2.

Tabel 2. Hasil Normalisasi Data Kelayakan Judul Tugas Akhir

\begin{tabular}{|c|c|c|c|c|c|c|c|}
\hline \multirow{2}{*}{ Data ke } & \multicolumn{6}{|c|}{ Data Transformasi } & \multirow{2}{*}{ Target } \\
\hline & $\mathbf{X}_{1}$ & $\mathbf{X}_{2}$ & $\mathbf{X}_{\mathbf{3}}$ & $\mathbf{X}_{4}$ & $\mathbf{X}_{5}$ & $\mathbf{X}_{6}$ & \\
\hline 1 & 0.5 & 0.9 & 0.1 & 0.9 & 0.5 & 0.1 & 1 \\
\hline 2 & 0.1 & 0.9 & 0.1 & 0.9 & 0.5 & 0.1 & 1 \\
\hline 3 & 0.5 & 0.9 & 0.1 & 0.9 & 0.9 & 0.5 & 1 \\
\hline 4 & 0.9 & 0.9 & 0.1 & 0.9 & 0.9 & 0.1 & 1 \\
\hline 5 & 0.9 & 0.9 & 0.1 & 0.9 & 0.9 & 0.1 & 1 \\
\hline 6 & 0.5 & 0.9 & 0.1 & 0.9 & 0.9 & 0.1 & 1 \\
\hline 7 & 0.5 & 0.9 & 0.1 & 0.9 & 0.9 & 0.1 & 1 \\
\hline 8 & 0.9 & 0.9 & 0.1 & 0.9 & 0.5 & 0.1 & 1 \\
\hline 9 & 0.5 & 0.9 & 0.1 & 0.9 & 0.5 & 0.1 & 1 \\
\hline 10 & 0.5 & 0.9 & 0.1 & 0.9 & 0.5 & 0.1 & 1 \\
\hline 11 & 0.9 & 0.9 & 0.1 & 0.9 & 0.9 & 0.5 & 0 \\
\hline 12 & 0.9 & 0.9 & 0.9 & 0.9 & 0.5 & 0.5 & 0 \\
\hline 13 & 0.9 & 0.9 & 0.9 & 0.9 & 0.5 & 0.5 & 0 \\
\hline 14 & 0.9 & 0.9 & 0.9 & 0.9 & 0.5 & 0.5 & 0 \\
\hline 15 & 0.9 & 0.9 & 0.1 & 0.9 & 0.5 & 0.5 & 0 \\
\hline 16 & 0.9 & 0.9 & 0.1 & 0.9 & 0.9 & 0.5 & 0 \\
\hline 17 & 0.9 & 0.9 & 0.1 & 0.9 & 0.9 & 0.9 & 0 \\
\hline 18 & 0.9 & 0.9 & 0.1 & 0.9 & 0.9 & 0.5 & 0 \\
\hline 19 & 0.9 & 0.9 & 0.1 & 0.1 & 0.5 & 0.1 & 0 \\
\hline 20 & 0.9 & 0.9 & 0.1 & 0.9 & 0.5 & 0.5 & 0 \\
\hline 21 & 0.9 & 0.9 & 0.9 & 0.9 & 0.9 & 0.5 & 1 \\
\hline 22 & 0.9 & 0.9 & 0.1 & 0.9 & 0.9 & 0.5 & 1 \\
\hline 23 & 0.5 & 0.9 & 0.1 & 0.9 & 0.5 & 0.5 & 1 \\
\hline 24 & 0.5 & 0.5 & 0.1 & 0.9 & 0.5 & 0.1 & 1 \\
\hline 25 & 0.9 & 0.9 & 0.1 & 0.9 & 0.9 & 0.1 & 1 \\
\hline 26 & 0.9 & 0.9 & 0.1 & 0.9 & 0.9 & 0.5 & 1 \\
\hline 27 & 0.9 & 0.9 & 0.1 & 0.9 & 0.9 & 0.5 & 1 \\
\hline 28 & 0.9 & 0.9 & 0.1 & 0.9 & 0.9 & 0.5 & 1 \\
\hline 29 & 0.5 & 0.9 & 0.1 & 0.9 & 0.5 & 0.5 & 1 \\
\hline 30 & 0.9 & 0.9 & 0.5 & 0.9 & 0.9 & 0.1 & 1 \\
\hline 31 & 0.9 & 0.9 & 0.9 & 0.9 & 0.9 & 0.9 & 0 \\
\hline 32 & 0.9 & 0.9 & 0.1 & 0.9 & 0.9 & 0.5 & 0 \\
\hline 33 & 0.9 & 0.9 & 0.1 & 0.9 & 0.9 & 0.5 & 0 \\
\hline 34 & 0.9 & 0.9 & 0.1 & 0.9 & 0.9 & 0.5 & 0 \\
\hline
\end{tabular}




\begin{tabular}{llllllll}
\hline 35 & 0.9 & 0.9 & 0.1 & 0.9 & 0.5 & 0.5 & 0 \\
\hline 36 & 0.9 & 0.9 & 0.1 & 0.9 & 0.9 & 0.5 & 0 \\
\hline 37 & 0.9 & 0.9 & 0.1 & 0.9 & 0.5 & 0.5 & 0 \\
\hline 38 & 0.5 & 0.9 & 0.1 & 0.9 & 0.5 & 0.5 & 0 \\
\hline 39 & 0.9 & 0.9 & 0.1 & 0.9 & 0.9 & 0.9 & 0 \\
\hline 40 & 0.9 & 0.9 & 0.1 & 0.9 & 0.9 & 0.9 & 0 \\
\hline
\end{tabular}

Bentuk arsitektur jaringan Saraf Tiruannya dapat dilihat pada gambar 3.

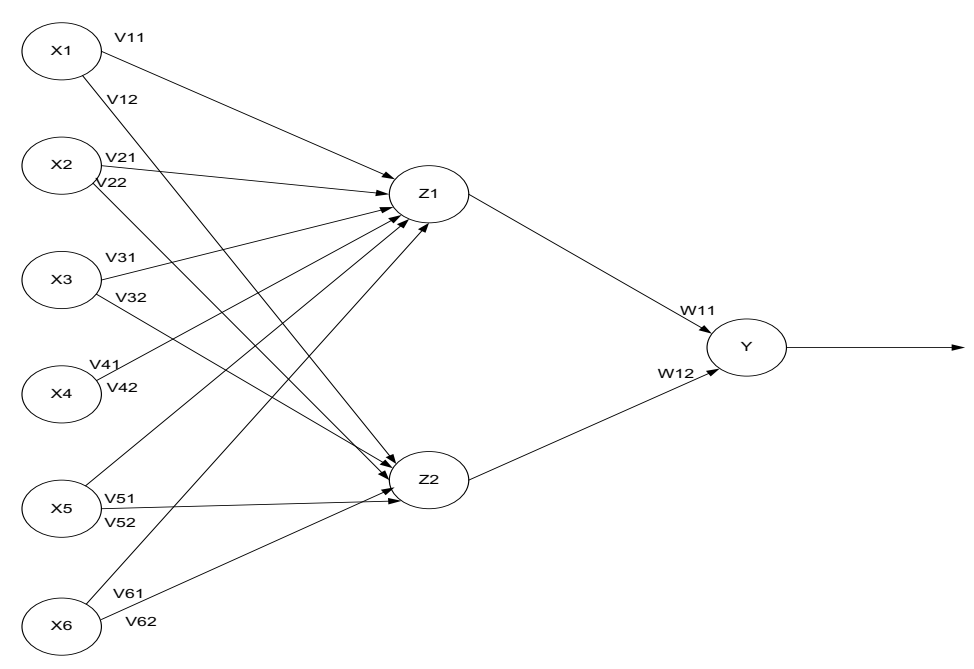

Gambar 3. Arsitektur Jaringan Backpropagation

Untuk nilai bobot awal lapisan input ke lapisan tersembunyi pertama seperti terlihat pada tabel 3 berikut.

Tabel 3. Bobot Awal dan Bobot Awal Bias Input

\begin{tabular}{rrrrrrr}
\hline & $\mathbf{Z}_{\mathbf{1}}$ & $\mathbf{Z}_{\mathbf{2}}$ & $\mathbf{Z}_{\mathbf{3}}$ & $\mathbf{Z}_{\mathbf{4}}$ & $\mathbf{Z}_{\mathbf{5}}$ & \multicolumn{1}{c}{$\mathbf{Z}_{\mathbf{6}}$} \\
\hline $\mathbf{X}_{\mathbf{1}}$ & 1.2241 & -0.7272 & 1.2552 & -0.6396 & 1.2209 & 1.2364 \\
\hline $\mathbf{X}_{\mathbf{2}}$ & 0.2965 & -0.0387 & 0.3276 & 0.0489 & 0.2933 & 0.3088 \\
\hline $\mathbf{X}_{\mathbf{3}}$ & 1.036 & 0.6902 & 1.0671 & 0.7778 & 1.0328 & 1.0483 \\
\hline $\mathbf{X}_{\mathbf{4}}$ & -0.0712 & -0.7836 & -0.0401 & -0.696 & -0.0744 & -0.0589 \\
\hline $\mathbf{X}_{\mathbf{5}}$ & 1.3241 & -0.5362 & 1.3552 & -0.4486 & 1.3209 & 1.3364 \\
\hline $\mathbf{X}_{\mathbf{6}}$ & 0.4673 & -0.8164 & 0.4984 & -0.7288 & 0.4641 & 0.4796 \\
\hline $\mathbf{V}_{\mathbf{j} \mathbf{0}}$ & -1.1621 & -2.319 & -1.131 & -2.2314 & -1.1653 & -1.1498 \\
\hline
\end{tabular}

Hasil dari proses pengolahan data secara manual selanjutnya akan diolah dengan Matlab menggunakan beberapa pola arsitektur. Hasil yang didapat selanjutnya akan dibandingkan dengan hasil pengolahan data secara manual untuk melihat perbedaan hasilnya.

Untuk melihat hasil pengujian dengan data pengujian dan target, gunakan perintah : $>>[\mathrm{m} 2, \mathrm{~b} 1, \mathrm{r} 2]=\operatorname{postreg}(\mathrm{b}, \mathrm{Tq})$, hasilnya akan terlihat pada gambar 4 . 


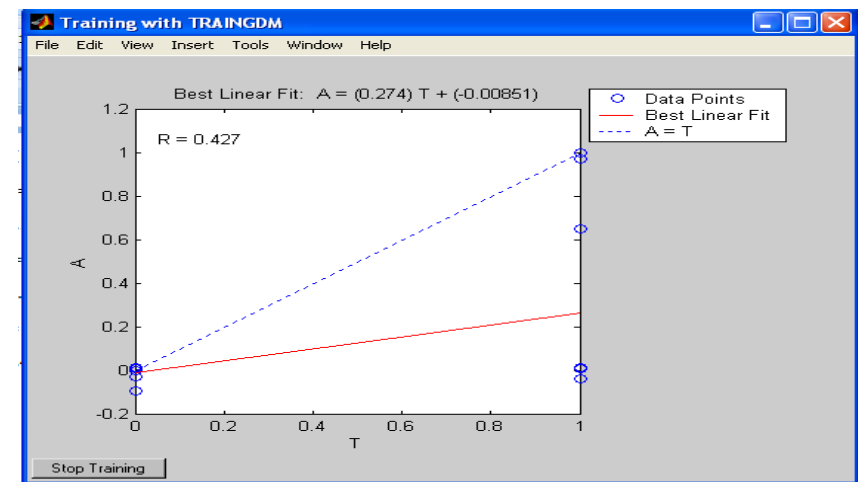

Gambar 4. Perbandingan Data Pengujian Dengan Target

Selanjutnya untuk melihat hasil pengujian dengan data pengujian dan target, maka gunakan perintah sebagai berikut:

$>>\mathrm{k}=[1: \operatorname{size}(\mathrm{q}, 2)]$;

$>$ plot(k,Tq,'bo',k, b','r*');

$>$ title('hasil pengujian dengan data pelatihan:target(o),output(*)');

>>xlabel('data ke-');ylabel('target/output');

Hasil dari perintah diatas akan terlihat pada gambar 5.

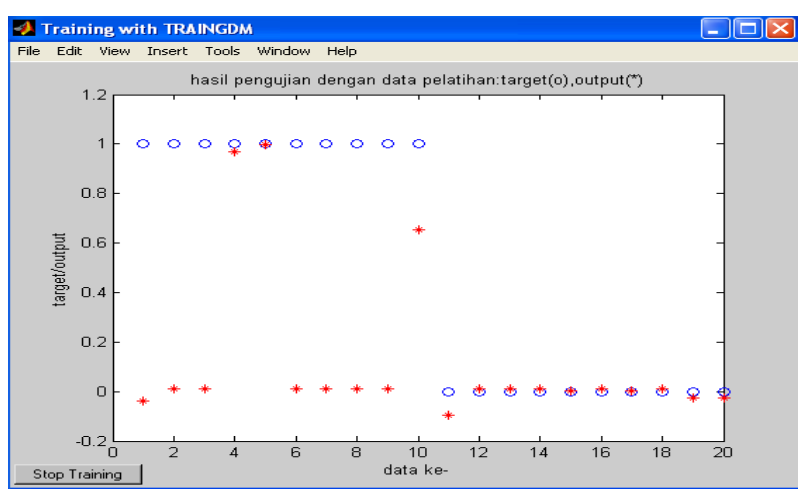

Gambar 5. Hasil Pengujian Dengan Data Pengujian Dan Target

Setelah melakukan pengolahan data menggunakan pola arsitektur 6-6-1 dengan 20 data pelatihan dan 20 data pengujian menggunakan Matlab, di peroleh hasil perbandingan antara target, hasil dan error, seperti terlihat pada tabel 4.

Tabel 4. Hasil Dan Error Data Input Pelatihan 6-6-1 (6x20)

\begin{tabular}{|c|c|c|c|c|c|c|c|c|c|c|}
\hline \multirow{2}{*}{ No } & \multicolumn{6}{|c|}{ Data Input Pelatihan } & \multirow{2}{*}{$\mathbf{T}$} & \multicolumn{2}{|c|}{ JST 6-6-1 } & \multirow{2}{*}{$\begin{array}{c}\text { Kondisi } \\
\text { KJST } \\
\end{array}$} \\
\hline & $\mathbf{X 1}$ & $\mathbf{X} 2$ & $\mathbf{X 3}$ & $\mathbf{X} 4$ & $\mathbf{X 5}$ & X6 & & Hasil & Error & \\
\hline 1 & 3 & 4 & 2 & 4 & 3 & 2 & 1 & 0.67 & 0.33 & T Layak \\
\hline 2 & 2 & 4 & 2 & 4 & 3 & 2 & 1 & 1.00 & -0.00 & Layak \\
\hline 3 & 3 & 4 & 2 & 4 & 4 & 3 & 1 & 0.97 & 0.03 & Layak \\
\hline 4 & 4 & 4 & 2 & 4 & 4 & 2 & 1 & 1.00 & 0.00 & Layak \\
\hline 5 & 4 & 4 & 2 & 4 & 4 & 2 & 1 & 1.00 & 0.00 & Layak \\
\hline 6 & 3 & 4 & 2 & 4 & 4 & 2 & 1 & 1.01 & -0.01 & Layak \\
\hline 7 & 3 & 4 & 2 & 4 & 4 & 2 & 1 & 1.01 & -0.01 & Layak \\
\hline
\end{tabular}




\begin{tabular}{|c|c|c|c|c|c|c|c|c|c|c|}
\hline 8 & 4 & 4 & 2 & 4 & 3 & 2 & 1 & 1.00 & 0.00 & Layak \\
\hline 9 & 3 & 4 & 2 & 4 & 3 & 2 & 1 & 1.00 & 0.00 & Layak \\
\hline 10 & 3 & 4 & 2 & 4 & 3 & 2 & 1 & 0.67 & 0.33 & T Layak \\
\hline 11 & 4 & 4 & 2 & 4 & 4 & 3 & 0 & 0.67 & -0.67 & Layak \\
\hline 12 & 4 & 4 & 4 & 4 & 3 & 3 & 0 & -0.00 & 0.00 & Layak \\
\hline 13 & 4 & 4 & 4 & 4 & 3 & 3 & 0 & -0.00 & 0.00 & Layak \\
\hline 14 & 4 & 4 & 4 & 4 & 3 & 3 & 0 & -0.00 & 0.00 & Layak \\
\hline 15 & 4 & 4 & 2 & 4 & 3 & 3 & 0 & $0.00-$ & 0.00 & Layak \\
\hline 16 & 4 & 4 & 2 & 4 & 4 & 3 & 0 & $0.01-$ & 0.01 & Layak \\
\hline 17 & 4 & 4 & 2 & 4 & 4 & 4 & 0 & -0.03 & 0.03 & Layak \\
\hline 18 & 4 & 4 & 2 & 4 & 4 & 3 & 0 & 0.01 & -0.01 & Layak \\
\hline 19 & 4 & 4 & 2 & 2 & 3 & 2 & 0 & 0.00 & -0.00 & Layak \\
\hline 20 & 4 & 4 & 2 & 4 & 3 & 3 & 0 & 0.00 & -0.00 & Layak \\
\hline \multicolumn{10}{|c|}{ Jumlah Keputusan Jaringan Saraf Tiruan yang Layak } & 18 \\
\hline \multicolumn{10}{|c|}{ Persentase } & $90 \%$ \\
\hline
\end{tabular}

Tabel diatas merupakan tabel pelatihan yang memiliki nilai terbaik dengan Jumlah Keputusan Jaringan Saraf Tiruan (KJST) yang Layak sebanyak 18 buah dari 20 data (90\%).

a. Hasil Pengolahan dengan Matlab

Pengolahan data dengan Matlab menggunakan beberapa pola arsistektur untuk mendapatkan hasil yang lebih baik, hasil persentase kebenaran terlihat pada tabel 5 .

Tabel 5. Hasil Pengolahan Matlab Berdasarkan Jumlah Data dan Arsitektur

\begin{tabular}{|c|c|c|c|c|c|c|}
\hline \multirow{2}{*}{ No } & \multicolumn{2}{|c|}{ Data } & \multirow{2}{*}{$\begin{array}{c}\text { Pola } \\
\text { Arsitektur }\end{array}$} & \multicolumn{2}{|c|}{ \% Kebenaran } & \multirow{2}{*}{ Ket } \\
\hline & Pelatihan & Pengujian & & Pelatihan & Pengujian & \\
\hline 1 & \multirow{5}{*}{20} & \multirow{5}{*}{20} & $6-2-1$ & $55 \%$ & $50 \%$ & \\
\hline 2 & & & $6-3-1$ & $55 \%$ & $50 \%$ & \\
\hline 3 & & & 6-4-1 & $55 \%$ & $50 \%$ & \\
\hline 4 & & & $6-5-1$ & $75 \%$ & $50 \%$ & \\
\hline 5 & & & 6-6-1 & $90 \%$ & $60 \%$ & Terbaik \\
\hline 6 & \multirow{5}{*}{25} & \multirow{5}{*}{15} & $6-2-1$ & $52 \%$ & $47 \%$ & \\
\hline 7 & & & $6-3-1$ & $52 \%$ & $47 \%$ & \\
\hline 8 & & & $6-4-1$ & $52 \%$ & $47 \%$ & \\
\hline 9 & & & $6-5-1$ & $64 \%$ & $47 \%$ & \\
\hline 10 & & & $6-6-1$ & $84 \%$ & $0 \%$ & \\
\hline 11 & \multirow{5}{*}{30} & \multirow{5}{*}{10} & $6-2-1$ & $53 \%$ & $50 \%$ & \\
\hline 12 & & & $6-3-1$ & $53 \%$ & $50 \%$ & \\
\hline 13 & & & $6-4-1$ & $53 \%$ & $50 \%$ & \\
\hline 14 & & & $6-5-1$ & $73 \%$ & $50 \%$ & \\
\hline 15 & & & $6-6-1$ & $90 \%$ & $50 \%$ & \\
\hline
\end{tabular}

Dari 15 kali percobaan di atas, didapat hasil ntuk pelatihan nilai persentase kebenaran paling tinggi $90 \%$ dan terendah $52 \%$ sedangkan untuk pengujian nilai persentase kebenaran tertinggi $60 \%$ dan terendah $0 \%$. Sehingga dapat disimpulkan bahwa hasil yang terbaik terletak pada pembagian data 20x20 dengan arsitektur 6-6-1. Dengan nilai persentase pelatihan $90 \%$ dan pengujian $60 \%$. 
b. Perbandingan Hasil Analisa Manual dengan Matlab

Analisa data secara manual dan secara sistematis sangat diperlukan, untuk memastikan apakah sistem yang kita gunakan telah bekerja sebagaimana mestinya, seperti pada tabel 6 .

Tabel 6. Perbandingan Hasil Pengolahan Data Matlab dengan Manual

\begin{tabular}{|c|c|c|c|c|c|c|c|c|c|c|c|c|c|c|c|c|c|}
\hline \multirow{2}{*}{$\begin{array}{l}\mathbf{N} \\
\mathbf{0}\end{array}$} & \multicolumn{6}{|c|}{ Kompetensi } & \multicolumn{6}{|c|}{ Normalisasi } & \multirow[t]{2}{*}{$\mathbf{T}$} & \multicolumn{2}{|c|}{ Matlab } & \multicolumn{2}{|c|}{ Manual } \\
\hline & X1 & $\mathbf{X} 2$ & $\mathbf{X 3}$ & $\mathbf{X} 4$ & $\mathbf{X 5}$ & X6 & X1 & $\mathbf{X 2}$ & $\mathbf{X 3}$ & $\mathrm{X} 4$ & X5 & X6 & & Hasil & Error & Hasil & Error \\
\hline 1 & 3 & 4 & 2 & 4 & 3 & 2 & 0,5 & 0,9 & 0,1 & 0,9 & 0,5 & 0,1 & 1 & 0.67 & 0.33 & 0.804 & 0.031 \\
\hline 2 & 2 & 4 & 2 & 4 & 3 & 2 & 0,1 & 0,9 & 0,1 & 0,9 & 0,5 & 0,1 & 1 & 1.00 & -0.00 & 0.765 & 0.042 \\
\hline 3 & 3 & 4 & 2 & 4 & 4 & 3 & 0,5 & 0,9 & 0,1 & 0,9 & 0,9 & 0,5 & 1 & 0.97 & 0.03 & 0.847 & 0.020 \\
\hline 4 & 4 & 4 & 2 & 4 & 4 & 2 & 0,9 & 0,9 & 0,1 & 0,9 & 0,9 & 0,1 & 1 & 1.00 & 0.00 & 0.859 & 0.017 \\
\hline 5 & 4 & 4 & 2 & 4 & 4 & 2 & 0,9 & 0,9 & 0,1 & 0,9 & 0,9 & 0,1 & 1 & 1.00 & 0.00 & 0.859 & 0.017 \\
\hline 6 & 3 & 4 & 2 & 4 & 4 & 2 & 0,5 & 0,9 & 0,1 & 0,9 & 0,9 & 0,1 & 1 & 1.01 & -0.01 & 0.837 & 0.022 \\
\hline 7 & 3 & 4 & 2 & 4 & 4 & 2 & 0,5 & 0,9 & 0,1 & 0,9 & 0,9 & 0,1 & 1 & 1.01 & -0.01 & 0.837 & 0.022 \\
\hline 8 & 4 & 4 & 2 & 4 & 3 & 2 & 0,9 & 0,9 & 0,1 & 0,9 & 0,5 & 0,1 & 1 & 1.00 & 0.00 & 0.835 & 0.023 \\
\hline 9 & 3 & 4 & 2 & 4 & 3 & 2 & 0,5 & 0,9 & 0,1 & 0,9 & 0,5 & 0,1 & 1 & 1.00 & 0.00 & 0.804 & 0.031 \\
\hline 10 & 3 & 4 & 2 & 4 & 3 & 2 & 0,5 & 0,9 & 0,1 & 0,9 & 0,5 & 0,1 & 1 & 0.67 & 0.33 & 0.804 & 0.031 \\
\hline
\end{tabular}

Dari perbandingan hasil manual dengan matlab pada tabel 3.6 menggunakan 10 data pelatihan 6x20 dengan arsitektur 6-6-1, maka akan terasa sulit untuk melihat persamaan hasil yang dicapai. Untuk mempermudah melihat persamaan hasil yang dicapai baik secara manual maupun Matlab, maka data hasil dan error dapat di ubah ke dalam skala 1 dan 0 , di mana bilangan dari 00.499 masuk kelas 0 dan bilangan $0.500-1$ masuk kelas 1 . Hasil transformasi data tersebut dilihat pada tabel 7 .

Tabel 7. Hasil Transformasi Data Hasil dan Error

\begin{tabular}{ccccccccc}
\hline \multicolumn{2}{c}{ Matlab } & \multicolumn{2}{c}{ Manual } & \multicolumn{2}{c}{ Matlab } & \multicolumn{2}{c}{ Manual } & \multirow{2}{*}{ Nilai } \\
\cline { 1 - 7 } Hasil & Error & Hasil & Error & Hasil & Error & Hasil & Error & \\
\cline { 1 - 7 } 0.67 & 0.33 & 0.804 & 0.031 & 1 & 0 & 1 & 0 & Sama \\
\hline 1.00 & -0.00 & 0.765 & 0.042 & 1 & 0 & 1 & 0 & Sama \\
\hline 0.97 & 0.03 & 0.847 & 0.020 & 1 & 0 & 1 & 0 & Sama \\
\hline 1.00 & 0.00 & 0.859 & 0.017 & 1 & 0 & 1 & 0 & Sama \\
\hline 1.00 & 0.00 & 0.859 & 0.017 & 1 & 0 & 1 & 0 & Sama \\
\hline 1.01 & -0.01 & 0.837 & 0.022 & 1 & 0 & 1 & 0 & Sama \\
\hline 1.01 & -0.01 & 0.837 & 0.022 & 1 & 0 & 1 & 0 & Sama \\
\hline 1.00 & 0.00 & 0.835 & 0.023 & 1 & 0 & 1 & 0 & Sama \\
\hline 1.00 & 0.00 & 0.804 & 0.031 & 1 & 0 & 1 & 0 & Sama \\
\hline 0.67 & 0.33 & 0.804 & 0.031 & 1 & 0 & 1 & 0 & \multirow{2}{*}{ Sama } \\
\hline
\end{tabular}

Dari 10 data pelatihan yang dibandingkan, terdapat sebanyak 10 data yang memiliki hasil output yang sama. Dari hasil tersebut maka dapat disimpulkan bahwa tingkat kepercayaan dari perbandingan data yang diolah dengan menggunakan Matlab dibandingkan dengan cara manual adalah $100 \%$.

\section{KESIMPULAN}

Penelitian ini telah berhasil dilakukan dan memberikan beberapa kesimpulan yaitu : 
1. Konsep Jaringan Saraf Tiruan (JST) dengan metode Backpropagation dapat diterapkan dalam memudahkan proses penyeleksian proposal Tugas Akhir (TA) mahasiswa D3 Manajemen Informatika AMIK-ROYAL KISARAN. Dengan metode ini dapat dibangun suatu jaringan yang meniru pada jaringan saraf manusia dengan metode pembelajaran Backpropagation.

2. Jaringan yang dibangun sudah dapat memberikan hasil yang dapat langsung dimengerti oleh pengguna, apakah suatu proposal judul Tugas Akhir (TA) layak atau tidak untuk diterima atau diteruskan.

\section{DAFTAR PUSTAKA}

[1] Arief Hermawan, 2006, Jaringan Syaraf Tiruan Teori dan Aplikasi, Ghara Ilmu, Yogyakarta.

[2] Diyah Puspitaningrum, 2006, Pengantar Jaringan Syaraf Tiruan, Andi Offset, Yogyakarta.

[3] Irfan Subakti, 2002, Sistem Pendukung Keputusan (Dicision Support System), Institut Teknogi Sepuluh November, Surabaya.

[4] Jong Jeng Siang, 2005, Jaringan Syaraf Tiruan \& Pemrogramannya menggunakan MATLAB, Andi Offset, Yogyakarta.

[5] Michael Neggnevitsky, 2002, Artificial Intelligece, Addison Wesley, Printed and bound in Geat by Biddles LTD, Guildford and King's Lynn, England.

[6] Sri Kusumadewi, 2003, Artificial Intelligence (Teknik dan Aplikasi), Andi Offset, Yogyakarta.

[7] Kiki, Sri Kusuma Dewi (Universitas Putra Indonesia), 2006, Analisis Jaringan Saraf Tiruan dengan Metode Backpropagation untuk Mendeteksi Gangguan Psikologi.

[8] M.F.Andrijasa, Mistianingsih, FMIPA Universitas Mulawarman, 2003, Penerapan Jaringan Saraf Tiruan untuk Memprediksi Jumlah Pengangguran di Provinsi Kalimantan Timur dengan Menggunakan Algoritma Pembelajaran Backpropagation.

[9] Novi Yanti, Jurusan Teknik Informatika, (Fakultas Sains dan Teknologi, Universitas Islam Negeri Sultan Syarif Kasim, Riau), 2004, Penerapan Metode Neural Network dengan Struktur Backpropagation untuk prediksi Stock Obat di Apotik (Studi Kasus : Apotek ABC). 